\title{
The Suitability of Cool and Warm Season Annual Cereal Species for Winter Grazing in Saskatchewan
}

\author{
W. E. May ${ }^{1}$, L. Klein ${ }^{2}$, and G. P. Lafond ${ }^{1}$, \\ ${ }^{1}$ Agriculture and Agri-Food Canada, Indian Head Research Farm, P. O. Box 760, Indian Head, \\ SK, S0G 2K0 (e-mail: mayb@agr.gc.ca) \\ ${ }^{2}$ Saskatchewan Agriculture, Food and Rural Revitalization, Weyburn, SK, 306-848-2382
}

\begin{abstract}
Cool and warm season annuals were seeded at Agri-Arm sites across Saskatchewan over three years to compare their suitability for winter grazing. Two seeding dates, eleven crops and two harvest times were used. The crops in this trial have significant differences in maturity. As expected, dry matter yield of the cool season annual cereals (oat, barley) tended to decrease with the later seeding date. Delayed seeding also decreased the yield of Golden German millet (foxtail millet) at two site years. Golden German millet had yields that were higher than oat at three site years, lower than oat at three site years and similar at 4 site years. Delaying the harvest lowered the protein level of all the crops. Seeding date did not consistently affect protein. Corn had significantly lower levels of protein than the other crops. As harvest was delayed forage biomass of the crops increased especially oat and barley. Weathering in the windrow until December had very little effect on the crude protein. Total digestible nutrients were not consistently affected by seeding date or harvest time. Temperature seemed to have a larger effect on the productivity of the warm season annuals than moisture. Golden German millet is well adapted for swath grazing on the eastern side of Saskatchewan. More data is required to determine its adaptability in central and western Saskatchewan.
\end{abstract}

\section{Introduction}

This research project is poised to answer the much-debated issue of the adaptive quality and potential for warm season crops as annual forages in Saskatchewan. In some areas, warm season crops tend to outperform cool season crops for forage. Studies conducted at the Brandon Research Centre have chronicled warm season crops advantages over cool season in dry matter production, especially for swath grazing (Byron Irvine, pers.comm.). Earlier studies evaluating old generation warm season grasses for greenfeed and silage have dissuaded their production in Saskatchewan. The availability of new species and varieties of warm season grasses has reopened this question especially for use in a swath grazing system. In addition, some cattle producers have begun to graze corn in the winter. If the provincial agricultural community is aiming to increase its cattle herd population, new innovative ideas need to be researched to provide farmers with the best information for feed production. The objective of this study is to evaluate annual cereal species for adaptation, quality, and yield production in annual fall and winter grazing systems. 


\section{Methods}

This test was conducted from 2002 to 2004 at the Agri-Arm locations listed in Table 1..

The plots were seeded in a split plot design with four replications. A complete set of plots was seeded mid May and again in mid June. It was expected the mid May seeding date would favour the cool season species, and the mid June seeding date would favour the warm season species.

Fertilizer was side banded during seeding at $50 \mathrm{lbs} /$ acre nitrogen and $20 \mathrm{lbs} /$ acre phosphorus. Two plots of corn were seeded; one at the above fertilizer rate, and a second with additional nitrogen at $120 \mathrm{lbs} /$ acre and double wide row spacing.

To determine the optimum crop stage for harvesting samples for forage yield and quality were collected on two separate dates from each plot. The first samples were collected at milk dough for oats, soft dough for barley, 50\% milk line for corn, and 2-3 weeks after heading for the millets and sorghum-sudangrass. The second samples were collected 2 weeks after the first sample.

To determine the suitability of the crops for swath grazing, a third set of samples for quality analysis were collected in December. These were collected from the mid June seeded plots that were windrowed after the second yield samples were collected. December samples were not collected for Siberian Red, Strain R, White Wonder, and Pearl millet.

Forage quality samples were analyzed at Norwest Labs in Lethbridge using wet chemistry FD6N package. 
Table 1. Species and Varieties Grown at 13 Site Years Across Saskatchewan From 2002 to 2004

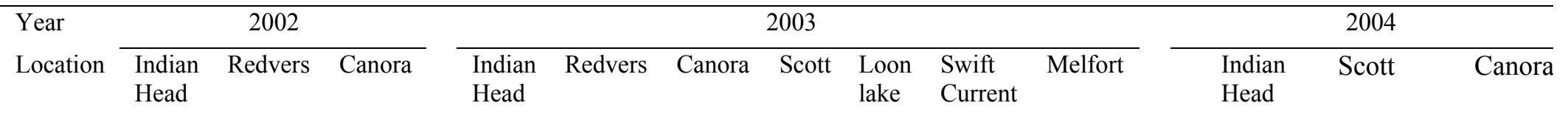

\begin{tabular}{|c|c|c|c|c|c|c|c|c|c|c|c|c|c|c|}
\hline Species & Variety & & & & & & & & & & & & & \\
\hline Oat $^{Z}$ & Pinnacle & $\mathrm{X}$ & $\mathrm{X}$ & $\mathrm{X}$ & $X$ & $\mathrm{X}$ & $\mathrm{X}$ & $\mathrm{X}$ & $\mathrm{X}$ & $\mathrm{X}$ & $\mathrm{X}$ & $\mathrm{X}$ & $\mathrm{X}$ & $\mathrm{X}$ \\
\hline Barley & Ranger & $\mathrm{X}$ & $\mathrm{X}$ & $\mathrm{X}$ & $X$ & $\mathrm{X}$ & $\mathrm{X}$ & $\mathrm{X}$ & $\mathrm{X}$ & $\mathrm{X}$ & $\mathrm{X}$ & $\mathrm{X}$ & $\mathrm{X}$ & $\mathrm{X}$ \\
\hline Proso Millet & $\begin{array}{l}\text { Crown } \\
\text { Millet }\end{array}$ & $\mathrm{X}$ & $\mathrm{X}$ & $\mathrm{X}$ & $X$ & $\mathrm{X}$ & $\mathrm{X}$ & $\mathrm{X}$ & $\mathrm{X}$ & $\mathrm{X}$ & $\mathrm{X}$ & $\mathrm{X}$ & $\mathrm{X}$ & $\mathrm{X}$ \\
\hline \multirow[t]{4}{*}{ Foxtail Millet } & $\begin{array}{l}\text { Siberian } \\
\text { Red } \\
\text { Millet }\end{array}$ & $\mathrm{X}$ & $\mathrm{X}$ & $\mathrm{X}$ & $\mathrm{X}$ & $\mathrm{X}$ & $\mathrm{X}$ & & & & & $\mathrm{X}$ & $\mathrm{X}$ & $\mathrm{X}$ \\
\hline & $\begin{array}{l}\text { Golden } \\
\text { German } \\
\text { Millet }\end{array}$ & $\mathrm{X}$ & $\mathrm{X}$ & $\mathrm{X}$ & $X$ & $\mathrm{X}$ & $\mathrm{X}$ & $\mathrm{X}$ & $\mathrm{X}$ & $\mathrm{X}$ & X & $\mathrm{X}$ & $\mathrm{X}$ & $\mathrm{X}$ \\
\hline & $\begin{array}{l}\text { White } \\
\text { Wonder }\end{array}$ & $\mathrm{X}$ & $\mathrm{X}$ & $\mathrm{X}$ & $\mathrm{X}$ & $\mathrm{X}$ & $\mathrm{X}$ & & & & & & & \\
\hline & $\begin{array}{l}\text { Strain R } \\
\text { German } \\
\text { Millet }\end{array}$ & $\mathrm{X}$ & $\mathrm{X}$ & $\mathrm{X}$ & $X$ & $\mathrm{X}$ & $\mathrm{X}$ & & & & & & & \\
\hline Pearl Millet & $\begin{array}{l}\text { Mil Hy } \\
300\end{array}$ & $\mathrm{X}$ & $\mathrm{X}$ & $\mathrm{X}$ & $X$ & $\mathrm{X}$ & $\mathrm{X}$ & & & & & $\mathrm{X}$ & $\mathrm{X}$ & $\mathrm{X}$ \\
\hline \multirow{3}{*}{$\begin{array}{l}\text { Sorghum-Sudangrass } \\
\text { Corn }\end{array}$} & & $\mathrm{X}$ & $\mathrm{X}$ & $\mathrm{X}$ & X & $\mathrm{X}$ & $\mathrm{X}$ & & & & \multirow{3}{*}{$\begin{array}{l}X \\
X\end{array}$} & $\mathrm{X}$ & $\mathrm{X}$ & $\mathrm{X}$ \\
\hline & $39 \mathrm{~T} 71$ & & & & $X$ & $\mathrm{X}$ & & $\mathrm{X}$ & $\mathrm{X}$ & $\mathrm{X}$ & & $\mathrm{X}$ & $\mathrm{X}$ & $\mathrm{X}$ \\
\hline & $39 \mathrm{~T} 71$ & & & & $\mathrm{X}$ & $\mathrm{X}$ & & $\mathrm{X}$ & $\mathrm{X}$ & $\mathrm{X}$ & & $\mathrm{X}$ & $\mathrm{X}$ & $\mathrm{X}$ \\
\hline
\end{tabular}

${ }^{\mathrm{z}}$ Species that were at all site years are highlighted in yellow 


\section{Results}

\section{Precipitation and Temperature}

Table 2 lists general spring moisture reserves and monthly precipitation at each site from April to August inclusive. Precipitation from April to August was below average at all sites in 2003 and at or above average in 2002 and 2004. Table 3 lists the average monthly temperatures.

Temperatures in 2004 tended to be much lower than in 2002 and 2003.

Table 2. Precipitation ( $\mathrm{mm}$ ) and Soil Moisture Conditions in Spring

\begin{tabular}{|c|c|c|c|c|c|c|c|c|c|c|c|c|}
\hline & \multicolumn{3}{|c|}{2002} & \multicolumn{6}{|c|}{2003} & \multicolumn{3}{|c|}{2004} \\
\hline & $\begin{array}{c}\text { Indian } \\
\text { Head }\end{array}$ & Redvers & Canora & Redvers & $\begin{array}{c}\begin{array}{c}\text { Indian } \\
\text { Head }\end{array} \\
\text { Hen }\end{array}$ & Canora & Melfort & $\begin{array}{c}\text { Swift } \\
\text { Current }\end{array}$ & Scott & $\begin{array}{c}\begin{array}{c}\text { Indian } \\
\text { Head }\end{array} \\
\text { Hed }\end{array}$ & Scott & Canora \\
\hline $\begin{array}{l}\text { Soil } \\
\text { Moisture } \\
\text { Reserves } \\
\text { (Spring) }\end{array}$ & $\begin{array}{c}\text { Poor } \\
\text { to } \\
\text { Fair }\end{array}$ & Fair & Fair & $\begin{array}{l}\text { Very } \\
\text { Good }\end{array}$ & $\begin{array}{l}\text { Very } \\
\text { Good }\end{array}$ & $\begin{array}{l}\text { Very } \\
\text { Good }\end{array}$ & Good & Good & Poor & Fair & Fair & Fair \\
\hline April & 19.5 & 15.6 & 17.4 & 19 & 55 & 15 & 28 & 52 & 5 & 17.1 & 2 & 9.8 \\
\hline May & 17.6 & 21.2 & 30.6 & 50 & 24 & 32 & 45 & 42 & 16 & 104.8 & 35 & 100.4 \\
\hline June & 115.4 & 86.8 & 116.6 & 35 & 18 & 29 & 52 & 79 & 34 & 85 & 52 & 79.6 \\
\hline July & 48.6 & 93.8 & 49.1 & 27 & 23 & 61 & 36 & 8 & 66 & 75.4 & 69 & 83.9 \\
\hline August & 98 & 125 & 116.8 & 36 & 11 & 9 & 24 & 21 & 44 & 71.2 & 44 & 95.1 \\
\hline TOTAL & 299 & 342 & 330 & 167 & 131 & 146 & 185 & 202 & 165 & 353.5 & 202 & 368 \\
\hline $\begin{array}{l}\text { Percent of } \\
\text { Average }\end{array}$ & 114 & 131 & 145 & 64 & 50 & 66 & 89 & 86 & 80 & 134 & 98 & 166 \\
\hline
\end{tabular}

Table 3. Monthly Mean Temperatures During the Study

\begin{tabular}{|c|c|c|c|c|c|c|c|c|c|c|c|c|}
\hline \multirow[b]{2}{*}{ Months } & \multicolumn{3}{|c|}{2002} & \multicolumn{6}{|c|}{2003} & \multicolumn{3}{|c|}{2004} \\
\hline & $\begin{array}{c}\begin{array}{c}\text { Indian } \\
\text { Head }\end{array} \\
\end{array}$ & Redvers & Canora & Redvers & $\begin{array}{c}\text { Indian } \\
\text { Head }\end{array}$ & Canora & Melfort & $\begin{array}{c}\text { Swift } \\
\text { Current }\end{array}$ & Scott & $\begin{array}{c}\text { Indian } \\
\text { Head }\end{array}$ & Scott & Canora \\
\hline & \multicolumn{12}{|c|}{${ }^{\circ} \mathrm{C}$} \\
\hline April & -0.6 & 1.6 & 0.6 & 5.3 & 4.3 & 4.1 & 3.7 & 6.3 & 4.1 & 3.7 & 4.7 & 4.4 \\
\hline May & 7.1 & 8.3 & 7.1 & 11.8 & 11.4 & 11.9 & 12.2 & 8.6 & 10.4 & 6.8 & 7.9 & 6.7 \\
\hline June & 15.8 & 16.8 & 16.6 & 16.2 & 15.5 & 15.9 & 15.7 & 12.9 & 14.4 & 12.6 & 12.6 & 12.9 \\
\hline July & 18.6 & 19.8 & 19.3 & 19.6 & 18.6 & 19.1 & 18.1 & 17.6 & 17.8 & 16.3 & 16.7 & 17.1 \\
\hline August & 15.7 & 16.7 & 16.5 & 21.2 & 19.5 & 19.8 & 19.8 & 15.3 & 20.0 & 13.1 & 14.0 & 13.9 \\
\hline
\end{tabular}




\section{Seed emergence}

The crops were established with direct seed equipment into standing stubble at most locations. At most time's even and strong emergence was obtained from the foxtail and proso millet varieties even when mid May. When soils were cold emergence was delayed and weeds became a larger problem. It was difficult to achieve consistent and even emergence from the sorghumsudangrass and pearl millet varieties used in this test. These two crops need to be special care and attention when a grower is trying to establish them. Corn emergence was consistent and fairly even.

Table 4. Days to First and Second Harvests for Early and Late Seeding at Indian Head in 2003.

\begin{tabular}{|c|c|c|c|c|c|c|c|c|}
\hline Early Seeding & & & & & & & & \\
\hline Days after seeding & 70 & 85 & 88 & 96 & 102 & 110 & 117 & 123 \\
\hline Pinnacle Oats & $1^{\text {st }}$ & $2^{\text {nd }}$ & & & & & & \\
\hline Ranger Barley & $1^{\text {st }}$ & $2^{\text {nd }}$ & & & & & & \\
\hline Crown Millet & & & $1^{\text {st }}$ & & $2^{\text {nd }}$ & & & \\
\hline Siberian Red Millet & & & & $1^{\mathrm{st}}$ & $2^{\text {nd }}$ & & & \\
\hline Golden German Millet & & & & & & $1^{\text {st }}$ & & $2^{\text {nd }}$ \\
\hline Strain R Millet & & & & & & $1^{\text {st }}$ & & $2^{\text {nd }}$ \\
\hline White Wonder Foxtail Millet & & & & & & $1^{\mathrm{st}}$ & & $2^{\text {nd }}$ \\
\hline Forage King Sorghum Sudan & & & & & & $1^{\text {st }}$ & & $2^{\text {nd }}$ \\
\hline Pearl Millet & & & & & & $1^{\text {st }}$ & & $2^{\text {nd }}$ \\
\hline Pioneer 39T71 Corn Low & & & & & $1^{\text {st }}$ & & $2^{\text {nd }}$ & \\
\hline Pioneer 39T71 Corn High & & & & & $1^{\mathrm{st}}$ & & $2^{\text {nd }}$ & \\
\hline Late Seeding & & & & & & & & \\
\hline Days after seeding & 62 & 70 & 77 & 84 & 91 & 97 & 106 & \\
\hline Pinnacle Oats & $1^{\text {st }}$ & $2^{\text {nd }}$ & & & & & & \\
\hline Ranger Barley & $1^{\text {st }}$ & $2^{\text {nd }}$ & & & & & & \\
\hline Crown Millet & & $1^{\text {st }}$ & $2^{\text {nd }}$ & & & & & \\
\hline Siberian Red Millet & & & $1^{\text {st }}$ & & $2^{\text {nd }}$ & & & \\
\hline Golden German Millet & & & & $1^{\text {st }}$ & & $2^{\text {nd }}$ & & \\
\hline Strain R Millet & & & & $1^{\text {st }}$ & & $2^{\text {nd }}$ & & \\
\hline White Wonder Foxtail Millet & & & & $1^{\text {st }}$ & & $2^{\text {nd }}$ & & \\
\hline Forage King Sorghum Sudan & & & & $1^{\mathrm{st}}$ & & $2^{\text {nd }}$ & & \\
\hline Pearl Millet & & & & $1^{\text {st }}$ & & $2^{\text {nd }}$ & & \\
\hline Pioneer 39T71 Corn Low & & & & & $1^{\mathrm{st}}$ & & $2^{\text {nd }}$ & \\
\hline Pioneer 39T71 Corn High & & & & & $1^{\mathrm{st}}$ & & $2^{\text {nd }}$ & \\
\hline
\end{tabular}




\section{Maturity}

The crops in this trial have significant differences in maturity, and the days to heading are affected by seeding date (Table 4). Crops seeded in mid June require fewer days to head than those seeded in mid May. Of the warm season crops, Crown millet is the earliest to head at 5060 days. Siberian Red millet heads at about 65-70 days. Golden German and White Wonder millet head at about 75-90 days. Strain R, Pearl millet and sorghum-sudangrass are the latest to head at about 80-95 days. The variety of corn used reach blacklayer or physiological maturity in 2003 but not 2004.

\section{Forage Yield}

There were significant differences among the crops at every location in every year (Table 5). At 10 out of the 13 locations the interaction between seeding date and crop was significant. This indicates that as the seeding date changed the ranking among the crops changed. In addition the interaction between harvest time and seeding date was significant at 7 out of the 13 locations. This indicates that about $50 \%$ of the time the crop rankings changed as harvest was delayed.

Table 5. Analysis of Variance for the response of forage yield to crop seeding date and harvest date for each individual site.

\begin{tabular}{|c|c|c|c|c|c|c|c|c|c|c|c|c|c|}
\hline \multirow[t]{2}{*}{ Effect } & \multicolumn{3}{|c|}{ Canora } & \multicolumn{3}{|c|}{$\begin{array}{c}\text { Indian } \\
\text { Head }\end{array}$} & \multirow{2}{*}{$\begin{array}{l}\text { Loon } \\
\text { lake } \\
2003 \\
\end{array}$} & \multirow{2}{*}{$\begin{array}{c}\text { Melfort } \\
2003 \\
\end{array}$} & \multicolumn{2}{|c|}{ Redvers } & \multicolumn{2}{|c|}{ Scott } & \multirow{2}{*}{$\begin{array}{c}\text { Swift } \\
\text { Current } \\
2003\end{array}$} \\
\hline & 2002 & 2003 & 2004 & 2002 & 2003 & 2004 & & & 2002 & 2003 & 2003 & 2004 & \\
\hline & \multicolumn{13}{|c|}{$P$ value } \\
\hline Crop & 0.000 & 0.000 & 0.000 & 0.000 & 0.000 & 0.000 & 0.000 & 0.000 & 0.000 & 0.000 & 0.000 & 0.000 & 0.000 \\
\hline seed date & 0.787 & 0.030 & 0.097 & 0.011 & 0.111 & 0.378 & 0.635 & 0.000 & 0.600 & 0.582 & 0.197 & 0.000 & 0.007 \\
\hline seed date*crop & 0.000 & 0.000 & 0.000 & 0.326 & 0.000 & 0.328 & 0.633 & 0.001 & 0.000 & 0.017 & 0.024 & 0.000 & 0.000 \\
\hline Harvest & & 0.201 & 0.000 & 0.002 & 0.000 & 0.000 & 0.173 & 0.000 & 0.000 & 0.000 & 0.188 & 0.087 & 0.000 \\
\hline harvest*crop & & 0.092 & 0.000 & 0.504 & 0.012 & 0.000 & 0.194 & 0.001 & 0.006 & 0.047 & 0.598 & 0.975 & 0.000 \\
\hline seed date*harvest & & 0.936 & 0.045 & 0.000 & 0.145 & 0.754 & & 0.000 & 0.714 & 0.568 & 0.802 & 0.343 & 0.001 \\
\hline seed date*harvest*crc & & 0.579 & 0.034 & 0.780 & 0.277 & 0.978 & & 0.009 & 0.161 & 0.827 & 0.496 & 0.806 & 0.000 \\
\hline
\end{tabular}

\section{Crop}

The yield for each crop averaged over seeding date and harvest date is presented in Table 6 for several site years. Oat and barely had similar yields at most site years. Golden German millet had a lower yield than oat or barley at Indian Head in 2004, Scott in 2004 and Swift Current in 2003. Golden German millet had a higher yield at Canora in 2002 and 2003than oat and barley, and higher than oat at Redvers in 2003. The yield of golden German millet was similar to oat and barley at four site years (Table 6). Crown millet was lower yielding than oat or barley at 7 of 10 site years. Sorghum-Sudan grass was very inconsistent in germination and yield. It only did well at Canora in 2002 and 2003 and Redvers in 2002. Corn was more consistent in its emergence and growth than sorghum-Sudan grass, with yields similar to oat and barley at Indian Head in 2003 and Melfort in 2003, higher than oat or barley at Redvers and Scott in 2003 and lower than oat or barley at Swift Current in 2003 and Scott in 2004. 
Table 6. The Yield of Individual Crops When Averaged over Seeding Date and Harvest Date

\begin{tabular}{|c|c|c|c|c|c|c|c|c|c|}
\hline \multirow[b]{2}{*}{ Site } & \multirow[b]{2}{*}{ Year } & Oat & Barley & $\begin{array}{l}\text { Foxtail } \\
\text { Millet }\end{array}$ & $\begin{array}{l}\text { Proso } \\
\text { Millet }\end{array}$ & $\begin{array}{l}\text { Sorghum } \\
\text { Sudan } \\
\text { grass }\end{array}$ & $\begin{array}{l}\text { Corn } \\
\text { Low }\end{array}$ & $\begin{array}{l}\text { Corn } \\
\text { high }\end{array}$ & \\
\hline & & Pinnacle & Ranger & $\begin{array}{c}\text { Golden } \\
\text { German Millet }\end{array}$ & Crown & & $39 \mathrm{~T} 71$ & 39T71 & LSD \\
\hline \multirow{3}{*}{ Canora } & & & & & $\mathrm{kg} / \mathrm{ha}$ & & & & \\
\hline & 2002 & 5.8 & 6.5 & 9.4 & 5.7 & 13.0 & & & 1.01 \\
\hline & 2003 & 7.0 & 9.5 & 11.6 & 11.1 & 9.4 & & & 2.08 \\
\hline \multirow[t]{2}{*}{ Indian Head } & 2003 & 4.8 & 5.6 & 5.1 & 3.4 & 3.3 & 5.0 & 5.6 & 0.56 \\
\hline & 2004 & 8.3 & 8.8 & 3.8 & 3.8 & 1.2 & 4.7 & 5.6 & 0.79 \\
\hline Melfort & 2003 & 8.7 & 9.5 & 8.9 & 7.3 & 4.5 & 9.5 & 12.1 & 1.01 \\
\hline \multirow[t]{2}{*}{ Redvers } & 2002 & 7.7 & 6.7 & 7.1 & 5.5 & 7.5 & & & 0.90 \\
\hline & 2003 & 5.9 & 6.6 & 6.9 & 5.6 & 4.5 & 9.3 & 8.8 & 0.76 \\
\hline \multirow[t]{2}{*}{ Scott } & 2003 & 5.4 & 5.9 & 5.2 & 6.3 & 2.9 & 11.4 & 13.7 & 1.56 \\
\hline & 2004 & 4.9 & 4.9 & 2.6 & 2.4 & 0.2 & 1.9 & 1.7 & 0.41 \\
\hline Swift Current & 2003 & 4.3 & 3.9 & 3.0 & 2.5 & 1.2 & 2.1 & 1.3 & 0.44 \\
\hline
\end{tabular}

\section{Seeding Date}

Seeding date did not have as great an effect on forage yield as was expected before the experiment was initiated. Delayed seeding reduced forage yield of oat at four site years, increased yield at one site year, and had no difference at 6 site years (Table 7). A similar response occurred in barley, with delayed seeding reducing forage yield at three site years, increasing yield at two site years, and no differences occurring at 6 site years. Surprisingly, the yield of Golden German millet decreased at two site years as seeding was delayed and did not increase at any site except at Indian Head were the early seeded golden German millet was completely over whelmed by wild oats. Therefore, the expected advantage from delayed seeding of golden German millet was not realized, however, a balance between early seeding and weed control must be achieved. All millets are very slow to emerge from the soil under cool conditions making them vulnerable to weed pressure especially from wild oat. The proso millet variety did have increased yields at two site years with delayed seeding. Weed pressure at the early seeding date at both these locations was observed but not quantified. Sorghum-sudangrass and both the low and high input corn increased yield as seeding was delayed at one site year and decreased yield at two site years, indicating that there was no consistent response by these treatments to seeding date.

\section{Harvest Time}

Averaged over all crops and locations, and both seeding dates, the second harvest tended to out yield the first harvest. This trend was most clearly seen for oats and barley (Table 8.) Both golden German millet (foxtail millet) and Crown millet (proso millet) only increased yield at two out of nine site years. It was expected that this trend would be much stronger than is indicated in Table 8 . Sorghum-sudangrass was only affected by harvest time at one site year. The low input corn increased yield as harvest was delayed at 4 out of 7 site years and high input corn increased yield at 2 out of 7 site years. Obviously the growing conditions near the end of August and early September are not always conducive to biomass production while the oats and barley are maturing much earlier in the season under more consistent growing conditions. 
The crop stage at first harvest was milk dough for oats and soft dough for barley. These are the recommended stages for greenfeed to optimize forage yield, quality and palatability. The second harvest for oats and barley was two weeks later, and in most cases they were too mature for greenfeed. Therefore, analysis of the data should focus more on the first harvest for oats and barley.

First harvest for the late maturing millets (Golden German, Strain R, White Wonder) was 2-3 weeks after heading, and second harvest was 2 weeks later. At second harvest the late maturing millets had remained quite green. It appears the second harvest may be the optimum time to harvest these crops.

The yields of first harvest oat and barley were compared to second harvest Golden German millet. At three site years first harvest oat out yielded the second harvest of golden German millet and at three site years golden German millet out yielded oat. When the results are averaged over all locations, it indicates that golden German millet is very competitive in the production of biomass (Table 9). The results from corn indicate that it can produce large amounts of biomass but is even more sensitive to the environment than golden German millet. 
Table 7. The Forage Yield of Each Crop at the Early and Late Seeding Dates Averaged over Harvest Date for Several Locations

\begin{tabular}{|c|c|c|c|c|c|c|c|c|c|c|c|c|c|c|c|c|}
\hline \multirow[b]{2}{*}{ Site } & \multirow{2}{*}{$\begin{array}{l}\text { Crop } \\
\text { Date } \\
\text { Year }\end{array}$} & \multicolumn{2}{|c|}{ Oat } & \multicolumn{2}{|c|}{ Barley } & \multicolumn{2}{|c|}{$\begin{array}{l}\text { G.G. } \\
\text { Millet }\end{array}$} & \multicolumn{2}{|c|}{$\begin{array}{l}\text { Crown } \\
\text { Millet }\end{array}$} & \multicolumn{2}{|c|}{$\begin{array}{l}\text { Sorghum-Sudan } \\
\text { grass }\end{array}$} & \multicolumn{2}{|c|}{$\begin{array}{l}\text { Corn } \\
\text { Low }\end{array}$} & \multicolumn{2}{|c|}{$\begin{array}{l}\text { Corn } \\
\text { high }\end{array}$} & \multirow[t]{2}{*}{ LSD } \\
\hline & & early & late & early & late & early & late & $\begin{array}{r}\text { early } \\
\text { to }\end{array}$ & tonne/ha & early & late & early & late & early & late & \\
\hline \multirow[t]{2}{*}{ Canora } & 2002 & 5.6 & 6.1 & 5.3 & 7.8 & 11.1 & 7.8 & 5.3 & 6.2 & 12.8 & 13.2 & & & & & 1.6 \\
\hline & 2003 & 6.0 & 8.0 & 8.4 & 10.7 & 13.0 & 10.1 & 10.8 & 11.5 & 12.9 & 5.8 & & & & & 3.2 \\
\hline \multirow[t]{3}{*}{ Indian Head } & 2002 & 5.6 & 7.3 & 6.3 & 7.7 & & 7.2 & & 5.7 & & 7.1 & & & & & 1.0 \\
\hline & 2003 & 5.4 & 4.2 & 6.1 & 5.2 & 5.4 & 4.8 & 3.5 & 3.3 & 3.7 & 2.8 & 5.4 & 4.5 & 7.0 & 4.2 & 0.92 \\
\hline & 2004 & 8.5 & 8.2 & 8.8 & 8.9 & 3.8 & 3.9 & 3.4 & 4.2 & 0.8 & 1.6 & 5.0 & 4.5 & 5.0 & 6.1 & 1.4 \\
\hline Melfort & 2003 & 9.9 & 7.4 & 11.0 & 8.0 & 9.7 & 8.1 & 7.1 & 7.5 & 5.0 & 4.0 & 10.5 & 8.5 & 14.2 & 10.0 & 1.4 \\
\hline \multirow[t]{2}{*}{ Redvers } & 2002 & 8.2 & 7.3 & 7.2 & 6.2 & 7.5 & 6.7 & 5.0 & 6.1 & 6.3 & 8.7 & & & & & 1.4 \\
\hline & 2003 & 5.9 & 5.9 & 6.5 & 6.7 & 7.2 & 6.6 & 5.2 & 6.0 & 3.7 & 5.3 & 8.6 & 9.9 & 8.4 & 9.2 & 1.9 \\
\hline \multirow[t]{2}{*}{ Scott } & 2003 & 5.0 & 5.9 & 5.5 & 6.4 & 5.2 & 5.1 & 6.6 & 6.1 & 3.4 & 2.4 & 9.6 & 13.2 & 12.1 & 15.2 & 2.4 \\
\hline & 2004 & 6.0 & 3.8 & 5.7 & 4.1 & 2.7 & 2.5 & 2.4 & 2.3 & 0.1 & 0.4 & 2.3 & 1.5 & 2.0 & 1.5 & 0.58 \\
\hline Swift Current & 2003 & 6.1 & 2.6 & 5.4 & 2.5 & 2.7 & 3.3 & 1.9 & 3.1 & 1.1 & 1.4 & 1.8 & 2.4 & 1.2 & 1.5 & 0.63 \\
\hline
\end{tabular}

Table 8. The Forage Yield of Each Crop at the First and Second Harvest Date Averaged over Seeding Date for Several Locations

\begin{tabular}{|c|c|c|c|c|c|c|c|c|c|c|c|c|c|c|c|c|}
\hline \multirow[b]{2}{*}{ Site } & \multirow{2}{*}{$\begin{array}{l}\text { Crop } \\
\text { Harvest } \\
\text { Year }\end{array}$} & \multicolumn{2}{|c|}{ Oat } & \multicolumn{2}{|c|}{ Barley } & \multicolumn{2}{|c|}{$\begin{array}{l}\text { G.G. } \\
\text { Millet }\end{array}$} & \multicolumn{2}{|c|}{$\begin{array}{l}\text { Crown } \\
\text { Millet }\end{array}$} & \multicolumn{2}{|c|}{ Sorghum-Sudan grass } & \multicolumn{2}{|c|}{ Corn Low } & \multicolumn{2}{|c|}{ Corn high } & \multirow[b]{2}{*}{ LSD } \\
\hline & & $1 \mathrm{st}$ & 2 nd & $1 \mathrm{st}$ & $2^{\text {nd }}$ & $1 \mathrm{st}$ & 2nd & $1 \mathrm{st}$ & 2nd & $1 \mathrm{st}$ & 2 nd & $1 \mathrm{st}$ & 2nd & $1 \mathrm{st}$ & 2 nd & \\
\hline & \multicolumn{16}{|c|}{ Tonne/ha } \\
\hline \multirow[t]{2}{*}{ Canora } & 2003 & 5.9 & 8.0 & 8.1 & 11.0 & 12.3 & 10.8 & 10.2 & 12.0 & 9.2 & 9.6 & & & & & 2.9 \\
\hline & 2004 & 9.5 & 15.7 & 10.8 & 12.6 & & 8.6 & & 9.0 & & 2.5 & & & & & 1.3 \\
\hline \multirow[t]{2}{*}{ Indian Head } & 2003 & 4.0 & 5.6 & 5.0 & 6.3 & 4.4 & 5.7 & 3.2 & 3.6 & 3.2 & 3.3 & 5.0 & 4.9 & 5.3 & 6.0 & 0.79 \\
\hline & 2004 & 6.9 & 9.8 & 7.1 & 10.6 & 3.8 & 3.9 & 3.6 & 4.0 & 1.3 & 1.2 & 4.0 & 5.5 & 5.2 & 6.0 & 1.1 \\
\hline Melfort & 2003 & 8.0 & 9.3 & 8.9 & 10.1 & 8.6 & 9.2 & 6.2 & 8.4 & 4.9 & 4.2 & 8.3 & 10.8 & 10.2 & 14.0 & 1.4 \\
\hline \multirow[t]{2}{*}{ Redvers } & 2002 & 7.3 & 8.1 & 6.3 & 7.1 & 6.1 & 8.0 & 5.6 & 5.5 & 5.8 & 9.1 & & & & & 1.3 \\
\hline & 2003 & 5.2 & 6.6 & 6.0 & 7.2 & 6.8 & 6.9 & 5.2 & 5.9 & 4.6 & 4.5 & 8.1 & 10.5 & 8.2 & 9.5 & 1.1 \\
\hline \multirow[t]{2}{*}{ Scott } & 2003 & 6.5 & 4.4 & 6.3 & 5.6 & 5.7 & 4.7 & 6.7 & 5.9 & 2.5 & 3.3 & 11.2 & 11.6 & 13.9 & 13.4 & 2.2 \\
\hline & 2004 & 5.1 & 4.6 & 4.9 & 4.9 & 2.7 & 2.5 & 2.4 & 2.3 & 0.2 & 0.2 & 2.1 & 1.7 & 1.8 & 1.7 & 0.58 \\
\hline Swift Current & 2003 & 5.6 & 3.0 & 4.8 & 3.1 & 2.9 & 3.0 & 2.7 & 2.3 & 1.0 & 1.4 & 1.8 & 2.5 & 1.3 & 1.4 & 0.62 \\
\hline
\end{tabular}

1 st is the first harvest taken for each individual crop, 2 nd is the second harvest taken for each individual crop 
Table 9. The Effect of Seeding Date, Harvest Date and Crop on Forage Yield When Locations are Combined

\begin{tabular}{lccccc}
\hline & \multicolumn{3}{c}{ Seeding date } \\
\cline { 2 - 3 } \cline { 5 - 6 } Crop & \multicolumn{2}{c}{ Mid May } & & \multicolumn{2}{c}{ Mid June } \\
\cline { 2 - 3 } \cline { 5 - 6 } 1st harvest & 2nd harvest & & Tonne/ha & \\
Oat & 6.49 & 7.38 & & 6.14 & 7.44 \\
Barley & 6.79 & 7.61 & 6.53 & 7.70 \\
Golden German millet & 6.47 & 6.52 & & 5.80 & 6.26 \\
Crown millet & 5.08 & 5.64 & & 5.39 & 6.13 \\
Sorghum-sudangrass & 4.67 & 3.85 & & 4.30 & 4.23 \\
LSD0.05 & 1.27 & & & \\
\hline
\end{tabular}

Table 10. Analysis Of Variance For The Response Of Protein To Crop Seeding Date And Harvest Date For Each Individual Site.

\begin{tabular}{|c|c|c|c|c|c|c|c|c|}
\hline Effect & $\begin{array}{c}\text { Canora } \\
2003\end{array}$ & $\begin{array}{c}\text { Indian } \\
\text { Head } \\
2003\end{array}$ & $\begin{array}{c}\text { Indian } \\
\text { Head } \\
2004\end{array}$ & $\begin{array}{c}\text { Melfort } \\
2003\end{array}$ & $\begin{array}{c}\text { Redvers } \\
2003\end{array}$ & $\begin{array}{l}\text { Scott } \\
2003\end{array}$ & $\begin{array}{l}\text { Scott } \\
2004\end{array}$ & $\begin{array}{c}\text { Swift } \\
\text { Current } \\
2003\end{array}$ \\
\hline & \multicolumn{8}{|c|}{$P$ value } \\
\hline Crop & 0.002 & 0.000 & 0.000 & 0.001 & 0.000 & 0.000 & 0.000 & 0.000 \\
\hline Seed date & 0.834 & 0.983 & 0.369 & 0.972 & 0.273 & 0.953 & 0.000 & 0.000 \\
\hline Seed date*crop & 0.024 & 0.026 & 0.329 & 0.376 & 0.205 & 0.144 & 0.018 & 0.050 \\
\hline harvest & 0.000 & 0.000 & 0.092 & 0.001 & 0.000 & 0.001 & 0.124 & 0.000 \\
\hline harvest ${ }^{*}$ crop & 0.554 & 0.378 & 0.369 & 0.278 & 0.151 & 0.939 & 0.010 & 0.001 \\
\hline Seed date*harvest & 0.180 & 0.153 & 0.739 & 0.237 & 0.295 & 0.419 & 0.294 & 0.897 \\
\hline Seed date*harvest*crop & 0.596 & 0.160 & 0.995 & 0.666 & 0.636 & 0.834 & 0.719 & 0.744 \\
\hline
\end{tabular}

\section{Crude Protein}

Crop was significant at all site years in Table 10. Seed date was only significant at 2 out of 8 site year while the interaction between crop and seed date was significant at only 1 site year. Harvest timing was significant at 6 out of 8 site years or $75 \%$ of the time. The crop $\mathrm{x}$ harvest interaction was significant at 2 out of 8 site years and the seed date $\mathrm{x}$ harvest and the seed date $\mathrm{x}$ harvest $\mathrm{x}$ crop interactions were not significant at any site year. Therefore harvest timing and crop had the largest effects on protein with few interactions

\section{Crop}

Corn had lower protein than the other crops except in 2004 when it was so cold very little cob development occurred. Golden German millet and crown millet did not have protein levels that were consistently different from oats and barley.

The protein requirements for beef cows, basis dry matter are 7\% in second trimester, 8-9\% in third trimester and 10-11\% post calving. Excluding Swift Current in 2003, all of the crops are $8 \%$ protein or greater, with the exception of corn. Corn tends to be marginal for protein and it may need to be supplemented, especially as cows are getting closer to calving. 
Table 11. The Effect Of Crop At Several Site Years On Protein

\begin{tabular}{lcccccccc}
\hline Crop & $\begin{array}{c}\text { Canora } \\
\text { 2003 }\end{array}$ & $\begin{array}{c}\text { Indian } \\
\text { Head }\end{array}$ & $\begin{array}{c}\text { Indian } \\
\text { Head }\end{array}$ & \multicolumn{7}{c}{ Melfort } & Redvers & Scott & Scott & $\begin{array}{c}\text { Swift } \\
\text { Current } \\
\end{array}$ \\
& 2003 & 2004 & 2003 & 2003 & 2003 & 2004 & 2003 \\
\hline Oat & 9.9 & 10.7 & 9.8 & 9.0 & 9.5 & & 11.1 & 8.9 \\
Barley & 9.4 & 9.4 & 10.3 & 9.7 & 7.9 & 12.5 & 10.1 & 7.2 \\
Golden German Millet & 9.0 & 10.8 & 11.6 & 9.5 & 8.2 & 12.5 & 11.9 & 6.7 \\
Crown millet & 10.1 & 11.1 & 12.7 & 9.4 & 8.1 & 13.4 & & 5.9 \\
Sorghum-sudangrass & & & 11.4 & 15.8 & 9.0 & 8.3 & 15.8 & 18.1 \\
Corn-low & & 7.4 & 12.9 & 7.0 & 5.7 & 10.8 & 12.7 & 6.5 \\
Corn-high & & 8.2 & 13.0 & 7.7 & 6.6 & 11.4 & 13.5 & 6.8 \\
LSD & 1.5 & 1.0 & 1.3 & 1.2 & 1.1 & 1.6 & 1.0 & 1.2 \\
\hline
\end{tabular}

Harvest Time

Protein declined in all crops as harvest was delayed (Table 12)

Table 12. Effect Of Sample Time On Forage Quality, Averaged Across Locations in 2003.

\begin{tabular}{|c|c|c|c|c|}
\hline \multicolumn{5}{|c|}{ Sample Time } \\
\hline Crop & First Harvest & Second Harvest & December & LSD 0.05 \\
\hline \multicolumn{5}{|l|}{$\mathrm{CP}(\%)$} \\
\hline Pinnacle Oats & 11.7 & 9.2 & 8.9 & \\
\hline Ranger Barley & 10.5 & 8.4 & 9.1 & \\
\hline Crown Millet & 10.8 & 9.0 & 7.8 & \\
\hline Golden German Millet & 10.6 & 9.8 & 10.3 & 1.4 \\
\hline $\begin{array}{l}\text { Forage King Sorghum- } \\
\text { Sudangrass }\end{array}$ & 10.7 & 9.4 & 9.5 & \\
\hline Corn & 8.0 & 7.5 & 8.2 & \\
\hline Corn (wide row/high $\mathrm{N}$ ) & 9.0 & 8.4 & 9.0 & \\
\hline Mean & 10.2 & 8.8 & 9.0 & 0.8 \\
\hline \multicolumn{5}{|l|}{ TDN (\%) } \\
\hline Pinnacle Oats & 68.4 & 66.1 & 58.7 & \\
\hline Ranger Barley & 67.7 & 63.7 & 59.4 & \\
\hline Crown Millet & 67.7 & 67.9 & 61.3 & \\
\hline Golden German Millet & 66.5 & 67.3 & 67.5 & 5.3 \\
\hline $\begin{array}{l}\text { Forage King Sorghum- } \\
\text { Sudangrass }\end{array}$ & 70.2 & 68.1 & 66.8 & \\
\hline Corn & 68.5 & 68.6 & 70.5 & \\
\hline Corn (wide row/high $\mathrm{N}$ ) & 68.5 & 68.8 & 70.5 & \\
\hline Mean & 68.2 & 67.2 & 65.0 & 3.8 \\
\hline
\end{tabular}




\section{Winter Quality for Swath Grazing (protein)}

The plots seeded in mid June were windrowed after the second harvest. The windrows were left in the field to simulate swath grazing, and sampled in December for quality analysis. Averaged across all locations, protein levels were maintained for all crops from second harvest to December (Table 12). This is consistent with previous swath grazing work that monitored feed quality in the windrow from September to December. It appears there is minimal risk of losing protein when leaving windrows in the field starting in September.

\section{Total Digestible Nutrients (TDN)}

There were significant differences among the crops at each site year. The other effect that was significant was the harvest $\mathrm{x}$ crop interaction which was significant at $50 \%$ of the sites. In General there was no clear effect of harvest and seeding date on TDN. The crop means averaged across all 2003 locations is presented in Table 12.

Table 13. Analysis of Variance for the response of total digestible nutrients to crop seeding date and harvest date for each individual site.

\begin{tabular}{|c|c|c|c|c|c|c|c|c|}
\hline Effect & $\begin{array}{c}\text { Canora } \\
2003\end{array}$ & $\begin{array}{c}\text { Indian } \\
\text { Head } \\
2003\end{array}$ & $\begin{array}{c}\text { Indian } \\
\text { Head } \\
2004\end{array}$ & $\begin{array}{c}\text { Melfort } \\
2003\end{array}$ & $\begin{array}{c}\text { Redvers } \\
2003\end{array}$ & $\begin{array}{l}\text { Scott } \\
2003\end{array}$ & $\begin{array}{l}\text { Scott } \\
2004\end{array}$ & $\begin{array}{c}\text { Swift } \\
\text { Current } \\
2003\end{array}$ \\
\hline & \multicolumn{8}{|c|}{$P$ value } \\
\hline Crop & 0.000 & 0.000 & 0.000 & 0.000 & 0.000 & 0.000 & 0.000 & 0.000 \\
\hline Seed date & 0.405 & 0.168 & 0.661 & 0.140 & 0.004 & 0.903 & 0.003 & 0.000 \\
\hline Seed date*crop & 0.915 & 0.686 & 0.825 & 0.061 & 0.000 & 0.488 & 0.001 & 0.000 \\
\hline Harvest & 0.030 & 0.290 & 0.396 & 0.054 & 0.117 & 0.076 & 0.000 & 0.001 \\
\hline harvest*crop & 0.907 & 0.098 & 0.002 & 0.030 & 0.017 & 0.060 & 0.001 & 0.048 \\
\hline Seed date*harvest & 0.132 & 0.408 & 0.511 & 0.249 & 0.625 & 0.012 & 0.019 & 0.600 \\
\hline Seed date*harvest* crop & 0.009 & 0.661 & 0.998 & 0.341 & 0.267 & 0.071 & 0.000 & 0.664 \\
\hline
\end{tabular}

The TDN requirements for beef cows, basis dry matter are 50\% in second trimester, $55 \%$ in third trimester, and $60 \%$ post calving. With one exception of Golden German millet at Canora, TDN for all crops at all locations is $55 \%$ or greater. There are few cases where TDN is less than $60 \%$.

\section{Winter Quality for Swath Grazing (TDN)}

The plots seeded in mid June were windrowed after the second harvest. The windrows were left in the field to simulate swath grazing, and sampled in December for quality analysis. Averaged across all 2003 locations, the earlier maturing crops (oats, barley, Crown millet) had statistically significant declines in TDN from second harvest to December (Table 12). The TDN losses were: oats $66.1 \%$ to $58.7 \%$, barley $63.7 \%$ to $59.4 \%$, Crown millet $67.9 \%$ to $61.3 \%$. TDN of later maturing crops (Golden German millet, sorghum-sudangrass and corn) remained statistically constant from second harvest to December in 2003. The analysis from the 2004 locations for TDN will be needed before we can conclude that late maturing warm season crops appear to have the ability to maintain quality into winter, making them suited for swath grazing. 


\section{Discussion and Conclusions}

Oat and barley are not ideally suited for swath grazing. To maximize yield under normal conditions, oats and barley need to be seeded May 20-25 to take advantage of spring moisture and cooler temperatures. As a general rule, for each week that seeding is delayed past May 25, expect a $10 \%$ loss in yield. This expected response did not always occur in this experiment. If oat and barley are seeded this early for swath grazing, they will have to be cut in early August. Windrows left in the field from early August to freeze-up are subjected to long daylight and warm temperatures with potential for significant weathering. Therefore, seeding of oat and barley needs to be delayed to mid June to delay cutting, but as stated above there is a high probability yield will be reduced.

The native tall grass prairie region of western Canada stretches through central Manitoba, in a wide band on either side of the Red River Valley. Before European settlement, the tall grass prairie was dominated by Big Bluestem (Andropogon gerardii), a warm season grass. Of the trial sites, Redvers, Indian Head and Canora are geographically the closest to the Red River Valley. In 2002 and 2003 these sites tended to showed Golden German millet had a significant yield advantage over oats and barley. In 2004 a very cool year the millets did not do very well. At Scott the millets appeared to struggle and had difficulty reaching heading. The adaptation of millets between the east and western parts of the province require further study and analysis of this data. .

In eastern Saskatchewan, later maturing millets such as Golden German, Strain R German and White Wonder appear to be suited for swath grazing. However, future seed supplies of Strain R German millet and White Wonder will most likely not be available. Seeding of warm season crops needs to be delayed until early June when the soil has warmed to a minimum daily soil temperature of $10^{\circ} \mathrm{C}$. Because of later maturity and tolerance to warmer temperatures, the crops remain green and continue to grow late in the season. They can be cut in early-mid September, just prior to a killing frost. There is little risk of weathering in the windrow due to short day length and cool temperatures.

\section{Acknowledgements}

We would like to thank, Saskatchewan Agriculture, Food and Rural Revitalization Staff, Todd Jorgenson, Al Foster, and Sherrilyn Phelps, the following Agri-Arm sites and their staff, South East Research Farm Inc., Indian Head Agricultural Research Foundation, East Central Research Foundation, Wheatland Conservation Area, and the Western Applied Research Corporation. Financial Contributions from SAFRR's Agriculture Development Fund, Indian Head Agriculture Research Foundation, Norwest Labs and Greenhouse Gas Mitigation Program for Canadian Agriculture. 